\title{
Effects of intensified conditioning on Epstein-Barr virus and cytomegalovirus infections in allogeneic hematopoietic stem cell transplantation for hematological malignancies
}

\author{
Li Xuan, Fen Huang, Zhiping Fan, Hongsheng Zhou, Xian Zhang, Guopan Yu, Yu Zhang, Can Liu, Jing Sun and \\ Qifa Liu*
}

\begin{abstract}
Background: Intensified conditioning regimens (increasing the intensity of standard myeloablative conditioning) for hematological malignancies in allogeneic hematopoietic stem cell transplantation (allo-HSCT) could reduce the relapse rate of the underlying disease, but it might simultaneously increase the transplant-related mortality including the mortality of infections. To explore whether intensified conditioning affected Epstein-Barr virus (EBV) and cytomegalovirus (CMV) infections, 185 patients undergoing allo-HSCT were enrolled.

Methods: A total of 104 cases received standard and 81 intensified conditioning. Cyclosporine A (CsA) withdrawal and/or donor lymphocyte infusion (DLI) were conducted in high-risk patients. The EBV-DNA and CMV-DNA levels of blood were monitored regularly by quantitative real-time polymerase chain reaction (RQ-PCR) and immune reconstitution of recipients were analyzed by flow cytometry.

Results: The 3-year cumulative incidence of EBV viremia, EBV-associated diseases and mortality of EBV-associated diseases were $25.3 \% \pm 4.6 \%, 10.5 \% \pm 3.4 \%$ and $0.0 \% \pm 0.0 \%$ in the standard group, compared with $45.6 \% \pm 6.5 \%$, $26.0 \% \pm 5.3 \%$ and $7.3 \% \pm 3.1 \%$ in the intensified group $(P=0.002, P=0.002, P=0.008)$. The 3 -year cumulative incidence of CMV viremia and CMV-associated diseases, mortality of CMV-associated diseases and incidence of bacterial and fungal infections were similar between the two groups $(P=0.855, P=0.581, P=0.933, P=0.142$, $P=0.182$, respectively). Multivariate analysis showed that intensified conditioning was one of the risk factors for EBV viremia and EBV-associated diseases $(P=0.037, P=0.037)$, but it had no effects on CMV infections. The percentage of $\mathrm{CD}^{+} \mathrm{T}$ cells and $\mathrm{CD} 4^{+} / \mathrm{CD} 8^{+}$ratio at 3 months post-transplantation were lower in the intensified group $(P=0.032, P=0.022)$. The 3-year OS and DFS in the standard group were $62.2 \% \pm 5.8 \%$ and $60.6 \% \pm 5.6 \%$, compared with $51.6 \% \pm 6.2 \%$ and $51.1 \% \pm 5.9 \%$ in the intensified group $(P=0.029, P=0.063)$.
\end{abstract}

Conclusions: Intensified conditioning represents a promising approach for high-risk hematological malignancies, although it affects early immune reconstitution of recipients and increases the incidence and mortality of EBV infections.

Keywords: Epstein-Barr virus, Cytomegalovirus, Conditioning, Hematological malignancies, Allogeneic hematopoietic stem cell transplantation

\footnotetext{
* Correspondence: iuqifa628@163.com

Department of Hematology, Nanfang Hospital, Southern Medical University,

Guangzhou 510515 China
} 


\section{Introduction}

Allogeneic hematopoietic stem cell transplantation (allo-HSCT) is a curative approach for hematological malignancies [1,2]. Besides graft-versus-host disease (GVHD), the two main causes of death after alloHSCT remain relapse of malignancy and infections $[3,4]$. The relapse rate exceeds $50 \%$ in patients with refractory hematological malignancies with a standard myeloablative (MA) regimen consisting of total body irradiation $(\mathrm{TBI}) /$ busulfan $(\mathrm{Bu})$ combined with cyclophosphamide (CY) [5]. Reduced-intensity conditioning (RIC) regimens have been advocated to reduce transplantation-associated toxicity in elderly or medically unfit patients [6,7]; however, disappointing results have been reported with RIC transplantation in patients with refractory hematological malignancies $[8,9]$. Some studies suggested that intensified conditioning regimens, which increased the intensity of standard myeloablative conditioning, could reduce tumor relapse, but it might simutaneously increase the transplant-related mortality (TRM) including the mortality of infections [10-12]. Therefore, overall survival (OS) did not improve significantly. To improve the outcomes of allo-HSCT for refractory hematological malignancies, we introduced a strategy of sequential intensified conditioning and early rapid tapering of prophylactic immunosupressants therapy for GVHD during the early stage after transplantation [13]. The results of this trial suggested that this strategy might reduce tumor relapse. Moreover, the nonrandomized data suggested that this strategy did not increase the incidence and mortality of bacterial and fungal infections [13], but the effect of this strategy on opportunistic viral infections needed further investigation.

Opportunistic viral infections, especially Epstein Barr virus (EBV) and cytomegalovirus (CMV) infections are one of the common complications after allo-HSCT. Both primary infections and reactivations of EBV and CMV may result in life-threatening diseases in recipients of allo-HSCT [14-17]. The occurrence of EBV and CMV infections and reactivations is influenced by several factors and closely related to the immune function [18-21]. Some studies showed that the intensity of conditioning might affect immune reconstitution of recipients after allo-HSCT $[22,23]$. To explore whether intensified conditioning affected EBV and CMV infections, we prospectively studied the incidence and mortality of EBV and CMV infections in the recipients of allo-HSCT following intensified or standard conditioning.

\section{Methods \\ Patients}

From February 2009 to December 2011, 189 consecutive patients with hematological malignancies received allo-
HSCT in our single institution. A total of 185 cases were enrolled in this prospective study, and 4 cases who died from regimen-related toxicity (RRT) or bacterial infection before hematopoietic reconstitution were not included. The median age was 28.0 years (range 1263 years). Seventy-two patients were female, and 113 were male. The primary diseases included acute leukemia (AL, $\mathrm{n}=149$ ), chronic myeloid leukemia (CML, $\mathrm{n}=28)$, lymphoma $(\mathrm{n}=5)$, myelodysplastic syndrome (MDS, $\mathrm{n}=2$ ) and blastic plasmacytoid dendritic cell neoplasm $(n=1)$. One hundred and twenty-five patients were in the status of complete remission (CR) (including patients with CML-chronic phase [CP]), and 60 were not in CR (NR) at the time of transplantation. All recipients were EBV-DNA negative in blood and 99 were EBV-VCA (viral capsid antigen, IgG) seropositive before transplantation. Two donors were EBV-DNA positive and became EBV-DNA negative with antiviral agents before collection of stem cells; 111 donors were EBV-seropositive. Seven recipients and nine donors were CMV-DNA positive in blood before transplantation. After antiviral treatment, they were all CMVDNA negative at the time of transplantation. One hundred and sixty-nine recipients and 171 donors were CMV-IgG positive (Table 1). The study was performed in accordance with the modified Helsinki Declaration, and the protocol was approved by our ethical review boards before study initiation. All recipients, donors and/or guardians provided written informed consent.

\section{Conditioning regimens}

Five conditioning regimens, including three standard MA and two intensified MA conditioning regimens were administrated. The standard conditioning was as follows: (1) TBI (4.5 Gy/day, $-5,-4$ days $)+C Y(60 \mathrm{mg} /$ $\mathrm{kg} /$ day, $-3,-2$ days) in 36 recipients; (2) Bu $(3.2 \mathrm{mg} / \mathrm{kg} /$ day, -7 to -4 days $)+\mathrm{CY}(60 \mathrm{mg} / \mathrm{kg} /$ day, $-3,-2$ days $)$ in 40 recipients; (3) $\mathrm{Bu}(3.2 \mathrm{mg} / \mathrm{kg} / \mathrm{day},-6$ to -3 days $)+\mathrm{Flu}$ (fludarabine, $30 \mathrm{mg} / \mathrm{m}^{2},-6$ to -2 days) in 28 recipients. The intensified conditioning included the following: (1) TBI (4.5 Gy/day, -5, -4 days) + CY + VP-16 (etoposide, $10-15 \mathrm{mg} / \mathrm{kg} /$ day, $-3,-2$ days) in 32 recipients; (2) Flu (30 $\mathrm{mg} / \mathrm{m}^{2} /$ day, -10 to -6 days) + Ara-C (cytarabine, $2.0 \mathrm{~g} / \mathrm{m}^{2} /$ day, -10 to -6 days) plus TBI $(4.5$ Gy/day, -5 , -4 days) $+C Y$ in 49 recipients [13]. The alternative rules of conditioning depended on the high risk factors for primary diseases and comorbidities at the time of transplantation. Generally, except those with severe comorbidities, patients with high-risk genetics and/or in NR at the time of transplantation all received intensified conditioning; patients with intermediate/low-risk genetics and in $C R$ at the time of transplantation all received standard conditioning (Table 1). 
Table 1 Patient, donor and transplants characteristics

\begin{tabular}{|c|c|c|c|}
\hline Patient characteristics & $\begin{array}{l}\text { Intensified myeloablative conditioning } \\
\qquad(n=81)\end{array}$ & $\begin{array}{l}\text { Standard myeloablative conditioning } \\
\qquad(n=104)\end{array}$ & P-value \\
\hline Female/Male & $31(38.3 \%) / 50(61.7 \%)$ & $41(39.4 \%) / 63(60.6 \%)$ & NS \\
\hline Median age, years (range) & $26(14-54)$ & $28(12-63)$ & NS \\
\hline \multicolumn{4}{|l|}{ Disease } \\
\hline ALL & $42(51.85 \%)$ & $23(22.1 \%)$ & \multirow[t]{7}{*}{$P<0.001$} \\
\hline AML & $17(21.0 \%)$ & $43(41.4 \%)$ & \\
\hline ALAL & $12(14.8 \%)$ & $12(11.5 \%)$ & \\
\hline$C M L$ & $6(7.4 \%)$ & $22(21.2 \%)$ & \\
\hline $\mathrm{HD} / \mathrm{NHL}$ & $3(3.7 \%)$ & $2(1.9 \%)$ & \\
\hline MDS & $0(0 \%)$ & $2(1.9 \%)$ & \\
\hline BPDCN & $1(1.25 \%)$ & $0(0 \%)$ & \\
\hline \multicolumn{4}{|l|}{ Disease status at the time of transplants } \\
\hline CR (including CML-CP) & $31(38.3 \%)$ & $94(90.4 \%)$ & \multirow[t]{2}{*}{$P<0.001$} \\
\hline NR (including CML-AP and BC) & $50(61.7 \%)$ & $10(9.6 \%)$ & \\
\hline \multicolumn{4}{|l|}{ EBV serostatus } \\
\hline D-/R- & $15(18.5 \%)$ & $21(20.2 \%)$ & \multirow[t]{4}{*}{ NS } \\
\hline $\mathrm{D}+/ \mathrm{R}-$ & $23(28.4 \%)$ & $27(26.0 \%)$ & \\
\hline $\mathrm{D}-/ \mathrm{R}+$ & 16(19.8\%) & $22(21.1 \%)$ & \\
\hline $\mathrm{D}+/ \mathrm{R}+$ & $27(33.3 \%)$ & $34(32.7 \%)$ & \\
\hline \multicolumn{4}{|l|}{ CMV serostatus } \\
\hline D-/R- & $4(4.9 \%)$ & $5(4.8 \%)$ & \multirow[t]{4}{*}{ NS } \\
\hline $\mathrm{D}+/ \mathrm{R}-$ & $3(3.7 \%)$ & $4(3.85 \%)$ & \\
\hline $\mathrm{D}-/ \mathrm{R}+$ & $3(3.7 \%)$ & $2(1.95 \%)$ & \\
\hline $\mathrm{D}+/ \mathrm{R}+$ & $71(87.7 \%)$ & 93(89.4\%) & \\
\hline \multicolumn{4}{|l|}{ Donor type } \\
\hline Sibling donor & $44(54.3 \%)$ & $73(70.2 \%)$ & \multirow[t]{3}{*}{$P=0.010$} \\
\hline Family donor & $11(13.6 \%)$ & $3(2.9 \%)$ & \\
\hline Unrelated donor & $26(32.1 \%)$ & $28(26.9 \%)$ & \\
\hline \multicolumn{4}{|l|}{ HLA typing } \\
\hline HLA-identical & 49 (60.5\%) & 79 (76.0\%) & \multirow[t]{6}{*}{ NS } \\
\hline One allele mismatched & $15(18.5 \%)$ & $15(14.4 \%)$ & \\
\hline Two alleles mismatched & $8(9.9 \%)$ & $8(7.7 \%)$ & \\
\hline Three alleles mismatched & $1(1.2 \%)$ & $1(0.95 \%)$ & \\
\hline Four alleles mismatched & $6(7.4 \%)$ & $1(0.95 \%)$ & \\
\hline Five alleles mismatched & $2(2.5 \%)$ & $0(0.0 \%)$ & \\
\hline \multicolumn{4}{|l|}{ Stem cell source } \\
\hline PBSCs & $63(77.8 \%)$ & 90 (86.5\%) & \multirow[t]{3}{*}{ NS } \\
\hline BM & $1(1.2 \%)$ & $0(0.0 \%)$ & \\
\hline $\mathrm{PBSC}+\mathrm{BM}$ & $17(21.0 \%)$ & $14(13.5 \%)$ & \\
\hline 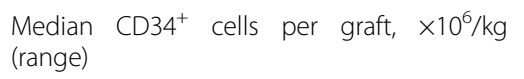 & 8.8(5.4-11.9) & $8.1(5.2-11.7)$ & NS \\
\hline \multicolumn{4}{|l|}{ Conditioning } \\
\hline $\mathrm{TBI}+\mathrm{CY}$ & & $36(34.6 \%)$ & \multirow[t]{3}{*}{ NA } \\
\hline $\mathrm{Bu}+\mathrm{CY}$ & & $40(38.5 \%)$ & \\
\hline $\mathrm{Bu}+\mathrm{Flu}$ & & $28(26.9 \%)$ & \\
\hline
\end{tabular}


Table 1 Patient, donor and transplants characteristics (Continued)

\begin{tabular}{lcc}
\hline Flu + Ara-c + TBI +CY & $49(60.5 \%)$ & \\
TBI + CY + VP-16 & $32(39.5 \%)$ & $2(1.9 \%)$ \\
GVHD prophylaxis & & $62(59.6 \%)$ \\
CSA & $4(5.0 \%)$ & $27(26.0 \%)$ \\
CSA + MTX & $33(40.75 \%)$ & $2(1.9 \%)$ \\
CSA + MTX + ATG & $28(34.5 \%)$ & $11(10.6 \%)$ \\
CSA + MTX + MMF & $3(3.7 \%)$ & NS \\
CSA + MTX + ATG + MMF & $13(16.05 \%)$ & \\
\hline
\end{tabular}

$A L L=$ acute lymphoblastic leukemia; $A M L=$ acute myelogenous leukemia; $A L A L=$ acute leukemia of ambiguous lineage; $C M L=$ chronic myelogenous leukemia; $H D=$ Hodgkin's disease; $N H L=$ Non-Hodgkin's lymphoma; $M D S=$ myelodysplastic syndromes; $B P D C N=$ blastic plasmacytoid dendritic cell neoplasm; $C R=$ complete remission; $C P=$ chronic phase; $N R=$ not in $C R ; A P=$ accelerated phase; $B C=$ blastic crisis; $D=$ donor; $R=$ recipient; $P B S C s=$ peripheral blood stem cells; $B M=$ bone marrow; $T B I=$ total body irradiation; $C Y=$ cyclophosphamide; $B U=$ busulfan; $F L U=$ fludarabine; $A r a-c=$ cytarabine; $V P 16=$ etoposide; $G V H D=$ graft-versus-host disease; $C S A=$ cyclosporine $\mathrm{A} ; M T X=$ methotrexate; $A T G=$ antithymocyte globulin; $M M F=$ mycophenolate mofetil; $N S=$ not significant; $N A=$ not applicable.

\section{Cyclosporine A (CsA) withdrawal and donor lymphocyte infusion (DLI) in high-risk patients}

According to the following criteria, CsA withdrawal and/or DLI were conducted in all patients with acute lymphoblastic leukemia (ALL) and high-risk factors (high-risk genetics or NR/>CR2 [second complete remission] at the time of transplantation). Depending on whether donor lymphocytes were available, CsA was withdrawn in two ways in patients who did not experience acute GVHD (aGVHD) by day +30 post-transplantation: if donor lymphocytes were unavailable, CsA was withdrawn rapidly in a stepwise fashion (ie, total dose reduced by $20 \% /$ week); if they were available, CsA was withdrawn in a stepwise fashion (ie, total dose reduced by $10 \% /$ week) and G-CSF mobilized donor lymphocytes $\left(1.0 \times 10^{8} / \mathrm{kg}\right.$, once a month, 4 doses totally) would be infused in patients without $\mathrm{II}^{\circ}$ or more than $\mathrm{II}^{\circ}$ aGVHD by day +60 post-transplantation. Once patients developed GVHD after DLI, DLI would stop and methylprednisolone was added to the regimen.

\section{Prophylaxis and treatment for GVHD}

CsA alone or CsA plus MTX (methotrexate) (on days +1 and +3 ) were administered in patients with NR undergoing HLA-matched sibling donor transplantation, and CsA plus MTX (on days $+1,+3$ and +6 ) were administered in patients with CR undergoing HLA matched sibling donor transplants for GVHD prophylaxis. CsA + MTX + ATG (antithymocyte globulin, for total doses of $6-10 \mathrm{mg} / \mathrm{kg}$, on days -3 to -1 or -4 to 0 ) and/ or MMF (mycophenolate) were used in patients undergoing HLA-mismatched related and unrelated donor transplants. Methylprednisolone (1-2 $\mathrm{mg} / \mathrm{kg} /$ day) was used to treat aGVHD. ATG or ATG combined with CD25 monoclonal antibody and other immunodepressants were used to treat glucocorticosteroid-resistant aGVHD. Corticosteroids and CsA were used initially to treat chronic GVHD (cGVHD) and were used in combination with various immunosuppressive agents to treat cGVHD that was unresponsive to initial therapy.

\section{Infection prophylaxis}

Oral sulfamethoxazole and norfloxacin were given to all patients. Acyclovir was given daily from the beginning of conditioning therapy to engraftment, and it was then administered daily for 7 days every 2 weeks until 1 year after transplantation. Ganciclovir was given for 2 weeks before transplantation for prophylaxis of CMV infections, and was administered once again when CMV viremia occurred. Antifungal agents were administered 5 days before transplantation. Fluconazole ( $0.3 \mathrm{~g} /$ day $)$ or itraconazole $(0.4 \mathrm{~g} / \mathrm{kg}$.d $)$ was used for up to +60 days post-transplantation in patients with no history of invasive fungal infection (IFI); those with a history of IFI received itraconazole $(0.4 \mathrm{~g} /$ day $)$, voriconazole (0.4 g/day), caspofungin (50 mg/day) or AmBisome (2 mg/kg.day) intravenously. Oral itraconazole or voriconazole was started when the peripheral white blood cell count exceeded $2.0 \times 10^{9} / \mathrm{L}$ and was discontinued after 90 days post-transplantation.

\section{Monitoring of EBV-DNA and CMV-DNA levels in blood}

Generally, the EBV-DNA and CMV-DNA levels of blood were monitored weekly for three months after transplantation. During the 4th to 9th month post-transplantation, the monitoring frequency was once every two weeks; the 10th to the 24th month, once a month; the 25th to 36th month, once every three months. If EBVDNA or CMV-DNA was positive, it was monitored twice a week.

The DNA levels of EBV and CMV in blood were detected by quantitative real-time polymerase chain reaction (RQ-PCR) $[24,25]$. The plasma $(50 \mu \mathrm{l})$ was mixed with $50 \mu \mathrm{l}$ of nucleic acid extract, and the mixture was 
heated at $99^{\circ} \mathrm{C}$ for 10 minutes and then centrifuged at $13000 \mathrm{rpm}$ for 10 minutes. The supernatant was collected for the next step. The PCR conditions for EBV were as follows: $37^{\circ} \mathrm{C}$ for 2 mins and $94^{\circ} \mathrm{C}$ for 2 mins followed by 40 cycles at $93^{\circ} \mathrm{C}$ for $15 \mathrm{~s}$ and $60^{\circ} \mathrm{C}$ for $1 \mathrm{~min}$. The sequences of the TaqMan probes and primers for EBV were as follows: EBV TaqMan probe.

(FAM)-TCTGCTGTTGTTTCTGTCTCACCTACCGG(TAMRA); EBV forward primer, 5'-CCAGTGCTGT GATCGAGCATCT-3'; and EBV reverse primer, 5'-CTGCTGACAAACTGCTGCATTC-3'. For CMV, the PCR conditions were as follows: 1 cycle at $50^{\circ} \mathrm{C}$ for 2 mins, $95^{\circ} \mathrm{C}$ for 10 mins and 45 cycles at $95^{\circ} \mathrm{C}$ for $15 \mathrm{~s}$ and $60^{\circ} \mathrm{C}$ for $1 \mathrm{~min}$. The forward primer was 5'-GAAGGTGCAGGTGCCCTG-3', the reverse primer 5'GTGTCGACGAACGACGTACG-3' and the probe (FAM)ACGGTGCTGTAGACCCGCATACAAA-(TAMRA). The normal threshold for EBV-DNA and CMV-DNA copies in plasma provided by the manufacturer (ZJ Bio-Tech Co.,Ltd., Shanghai, China) was less than 500 copies $/ \mathrm{ml}$. EBV-DNA or CMV-DNA was considered positive when the copies exceeded 500 copies $/ \mathrm{ml}$.

\section{Intervention for EBV and CMV viremia}

Once EBV-DNA or CMV-DNA in the blood was positive, the viral loads would be detected once again the next day. When EBV-DNA in the blood was positive twice consecutively, several measures of control were taken, including administration of antiviral agents (ganciclovir, acyclovir or foscarnet), immunoglobulin $(0.4 \mathrm{~g} / \mathrm{kg} / \mathrm{d} \times 3 \mathrm{~d})$ and reduction of immunosuppression if the condition of the patient was acceptable. If EBV-DNA in the blood was continuously positive four times with a rising trend, antiCD20 antibody (rituximab, $375 \mathrm{mg} / \mathrm{m}^{2}$ ) was administered weekly until EBV-DNA was negative or for a total of 4 weeks.

When CMV-DNA in the blood was positive twice consecutively, ganciclovir or foscarnet was administrated. If CMV-DNA in the blood was continuously positive four times with a rising trend, several measures of control were taken, including immunoglobulin $(0.4 \mathrm{~g} / \mathrm{kg} / \mathrm{d} \times 3 \mathrm{~d})$, reduction of immunosuppression and the combination of antiviral agents (ganciclovir and foscarnet).

\section{Diagnosis of EBV-and CMV-associated diseases}

EBV-associated diseases were classified into EBVassociated post-transplant lymphoproliferative diseases (PTLD) and EBV-associated other diseases. The diagnosis of EBV-associated PTLD was according to the criteria of World Health Organization (WHO) [26,27]. The diagnosis of EBV-associated other diseases was based on the criteria of the European Conference on Infections in Leukemia and literatures [17,28,29], which included EBV-associated fever without tissue involvement, EBV- associated diseases with tissue other than lymphatic tissue involvement.

CMV-associated diseases were defined according to published recommendations [15]. Briefly, CMV-associated disease was defined by the presence of clinical symptoms or signs of end organ disease, combined with the evidence of CMV infection in a tissue biopsy specimen. CMV pneumonia was diagnosed on the basis of signs and symptoms compatible with a diagnosis of pneumonia (hypoxemia, $\mathrm{x}$-ray) and a bronchoalveolar lavage (BAL) fluid or lung biopsy specimen positive for CMV by immunohistology. CMV gastrointestinal (GI) disease was diagnosed when GI signs or symptoms occurred, and evidence of CMV in the GI tract was diagnosed by immunohistochemistry or in situ hybridization from biopsy specimens. CMV encephalitis was defined by the identification of central nervous system symptoms together with the detection of CMVDNA in cerebrospinal fluid samples.

Once EBV- or CMV-associated diseases were considered or diagnosed, other viruses DNA including herpes simplex virus (HSV) -types 1 and 2, adenovirus (ADV), varicella zoster virus (VZV), human herpesvirus 6-8 (HHV6-8), parvovirus B19 and BK virus (BKV) were detected in blood (VZV and parvovirus B19 were detected by kit provided by ZJ Bio-Tech Co.,Ltd., Shanghai. HSV, ADV, HHV6-8 and BKV were detected by kit provided by Huayin medical technology Co.,Ltd., Guangzhou.). BKV were measured using RQ-PCR (Eppendorf AG, Hamburg, Germany), and other viruses were measured using qualitative PCR.

\section{Treatment of EBV- and CMV-associated diseases}

Once EBV-associated diseases were diagnosed, several measures would be taken promptly, including antiviral agents, reduction of immunosuppression, rituximab, combination chemotherapy, DLI and EBV-specific cytotoxic lymphocyte (EBV-CTL) treatment.

Once CMV-associated diseases were diagnosed, several measures would also be taken promptly, including administration of ganciclovir and foscarnet, immunoglobulin $(0.4 \mathrm{~g} / \mathrm{kg} / \mathrm{d} \times 3 \mathrm{~d})$ and reduction of immunosuppression.

\section{Flow cytometry analysis}

T lymphocyte subgroups $\left(\mathrm{CD}^{+}, \mathrm{CD}^{+} \mathrm{CD}^{+}, \mathrm{CD}^{+} \mathrm{CD}^{+}\right)$, $B$ lymphocytes $\left(\mathrm{CD} 19^{+}\right)$and NK cells $\left(\mathrm{CD} 16^{+} \mathrm{CD}^{+} 6^{+}\right)$in peripheral blood of recipients were analyzed by flow cytometry, respectively, at 1,3 and 6 months after transplantation. FITC-conjugated mouse anti-human CD3 (HIT3a), APC-conjugated anti-human CD4 (RPA-T4), PE-conjugated anti-human CD8 (HIT8a), PerCP-Cy5.5conjugated anti-human CD19 (HIB19), PE-conjugated anti-human CD16 (3 G8), PerCP-Cy5.5-conjugated anti-human CD56 (B159) were purchased from BD 
Pharmingen. Freshly isolated peripheral blood were incubated with FITC-, PE-, APC- and PerCP-Cy5.5conjugated $\mathrm{mAbs}$ or their isotype control Abs for $30 \mathrm{~min}$ at $4^{\circ} \mathrm{C}$, followed by hemolysis liquid washing and phosphate-buffered saline solution washing. All samples were assayed by BD FACSCanto ${ }^{\text {TM }}$ II (BD Biosciences) and the acquired data were further analyzed using BD-FACSDiva Software. Flow cytometric results were represented as percentage positive.

\section{Evaluation points and statistics}

Our data was analyzed on May 31, 2012. The main evaluation points included EBV and CMV infections within 3 years post-transplantation as well as bacterial and fungal infections within 100 days posttransplantation. The secondary evaluation points included hematopoietic engraftment, primary disease response, aGVHD, cGVHD, immune reconstitution, recurrence and survival. Comparisons of categorical variables were made by means of chi-squared and Fisher exact tests for small numbers. Differences between numerical variables were calculated by means of the Mann-Whitney $U$-test. Incidence of timedependent variables was estimated by the method of Kaplan-Meier. Intervals were measured from the day of transplantation until first diagnosis of EBV or CMV infections or until the last day of followup, transplant-related death or relapse. Univariate and multivariate Cox regression models were used to analyze risk factors for EBV and CMV infections after transplantation as well as OS and DFS (disease-free survival). EBV and CMV infections as well as OS and DFS were entered as time-dependent covariates. Variables for the multivariate models were selected with backward stepwise elimination with significance exceeding 0.05 as the criterion for removal from the models. A variable indicating whether patients were in the intensified or standard group was included in the models regardless of its significance.

\section{Results}

\section{Patient, donor and transplants characteristics}

The characteristics of patients, donors and transplants are summarized in Table 1 . There were significant differences between standard and intensified group in the category of diseases $(P<0.001)$, disease status at the time of transplantation $(P<0.001)$ and donor type $(P=0.010)$. As could be seen from the comparison, more patients in the intensified group were cases with ALL and/or in NR, receiving more family or unrelated donor transplants compared with standard group.

\section{Hematopoietic engraftment and primary disease response}

Of the 189 consecutive patients undergoing transplantation, 4 cases ( 3 in the intensified group, 1 in the standard group) died from RRT or bacterial infection before hematopoietic reconstitution and were not included. Regeneration of neutrophil counts $>0.5 \times 10^{9} / \mathrm{L}$ took a median of 11 days (range 9-22 days) and 12 days (range 9-31 days) in the standard and intensified group $(P=0.486)$, respectively. Platelet counts $>20 \times 10^{9} / \mathrm{L}$ were reached after a median of 12 days (range 940 days) and 13 days (range 9-70 days) in the standard and intensified group $(P=0.029)$, respectively. The sixty patients in NR at the time of transplantation, including 50 cases in the intensified group and 10 in the standard group, all achieved CR by day +30 post-transplantation.

\section{CsA withdrawal and DLI}

CsA was withdrawn in $42(40.4 \%)$ cases in the standard group and $50(61.7 \%)$ in the intensified group according to the criteria aforementioned $(P=0.004) .16 .3 \%(17 /$ $104)$ and $45.7 \%(37 / 81)$ cases received DLI in the standard and intensified group, respectively $(P<0.001)$. Thirtyeight cases who met the criteria of DLI did not receive DLI because of the limitation of the donor lymphocytes source, including 25 cases in the standard group and 13 in the intensified group $(P=0.182)$.

\section{GVHD}

Ninety-six cases developed aGVHD including 13 after DLI; 80 of 164 cases surviving more than 100 days developed cGVHD, including 20 after DLI. Grade I-IV aGVHD occurred in 49 of 104 (47.1\%) patients in the standard group (grade I, $\mathrm{n}=13$; grade II, $\mathrm{n}=29$; grade III, $\mathrm{n}=5$; grade IV, $\mathrm{n}=2$ ), compared with 47 of 81 $(58.0 \%)$ cases in the intensified group (grade $\mathrm{I}, \mathrm{n}=8$; grade II, $\mathrm{n}=28$; grade III, $\mathrm{n}=7$; grade $\mathrm{IV}, \mathrm{n}=4$ ) $(P=0.141)$. cGVHD occurred in 43 of $94 \quad(45.7 \%)$ patients in the standard group (limited, $\mathrm{n}=25$; extensive, $n=18)$, compared with 37 of $70(52.9 \%)$ cases in the intensified group (limited, $\mathrm{n}=27$; extensive, $\mathrm{n}=10$ ) $(P=0.367)$. In order to rule out the effects of immunosuppressants withdrawal and DLI on GVHD, the incidence of aGVHD I-IV and II- IV by day +30 was compared in the two groups. Acute GVHD I-IV and IIIV occurred in $31.7 \%$ (33/104) and $4.81 \%$ (5/104) patients by day +30 post-transplantation in the standard group, compared with $43.2 \%(35 / 81)$ and $12.3 \%(10 / 81)$ cases in the intensified group $(P=0.108, P=0.062$, respectively).

\section{Infections within 100 days post-transplantation}

Within the first 100 days post-transplantation, 101 cases developed 150 episodes of infections. Comparing 
standard versus intensified conditioning, 20 vs 13 had bacterial infections, 2 vs 5 had IFI, 9 vs 7 had viral infections except CMV and EBV viremia, 15 vs 22 had mixed infections and 5 vs 3 had infections of unknown etiology. The infection rates and the incidence of bacterial and fungal infections within 100 days post-transplantation were $49.0 \%, 32.7 \%$ and $11.5 \%$ in the standard group, compared with $61.7 \%, 43.2 \%$ and $18.5 \%$ in the intensified group ( $P=0.085, P=0.142, P=0.182$, respectively). Eight cases died of infections within 100 days post-transplantation, including three who died of CMV-associated diseases and two who died of EBV-associated diseases.

\section{EBV viremia and EBV-associated diseases}

With a median follow-up of 319 days post-transplantation (range, 27 to 1194 days), 57 cases (30.4\%) developed EBV viremia and 28 (15.1\%) developed EBV-associated diseases including 16 EBV- PTLD and 12 EBV-associated other diseases (7 EBV-associated fever, 1 encephalitis, 1 myelitis, 1 encephalitis with lung involvement, 1 encephalitis with lung and liver involvement and 1 pneumonia). EBV-associated diseases occurred in 2 (2\%), 1 (50\%) and 9 (34.6\%) cases receiving transplants from matched sibling donor, matched family donor and matched unrelated donor; they occurred in 4 (23.5\%), 4 (33.3\%) and 8 (28.6\%) cases from mismatched sibling donor, mismatched family donor and mismatched unrelated donor. The median time to onset of EBV viremia and EBVassociated diseases was 51 days (range, 22-368 days) and 63 days (range, 22-289 days) post-transplantation, respectively.

EBV viremia occurred in 24 (23.1\%) cases in the standard group and $33(40.7 \%)$ cases in the intensified group $(P=0.010)$. EBV-associated diseases occurred in $9(8.7 \%)$ cases in the standard group, including $4 \mathrm{EBV}$-associated fever, 4 PTLD and 1 encephalitis with lung and liver involvement; they occurred in $19(23.5 \%)$ cases in the intensified group, including $3 \mathrm{EBV}$ - associated fever, 12 PTLD, 1 encephalitis, 1 myelitis, 1 encephalitis with lung involvement and 1 pneumonia $(P=0.005)$. The 3 -year cumulative incidence of EBV viremia and EBVassociated diseases were $25.3 \% \pm 4.6 \%$ and $10.5 \% \pm 3.4 \%$ in the standard group, compared with $45.6 \% \pm 6.5 \%$ and $26.0 \% \pm 5.3 \%$ in the intensified group $(P=0.002$, $P=0.002$, respectively, log-rank test, Figure $1 \mathrm{~A}$ and $1 \mathrm{~B}$ ). No case in the standard group and five cases in the
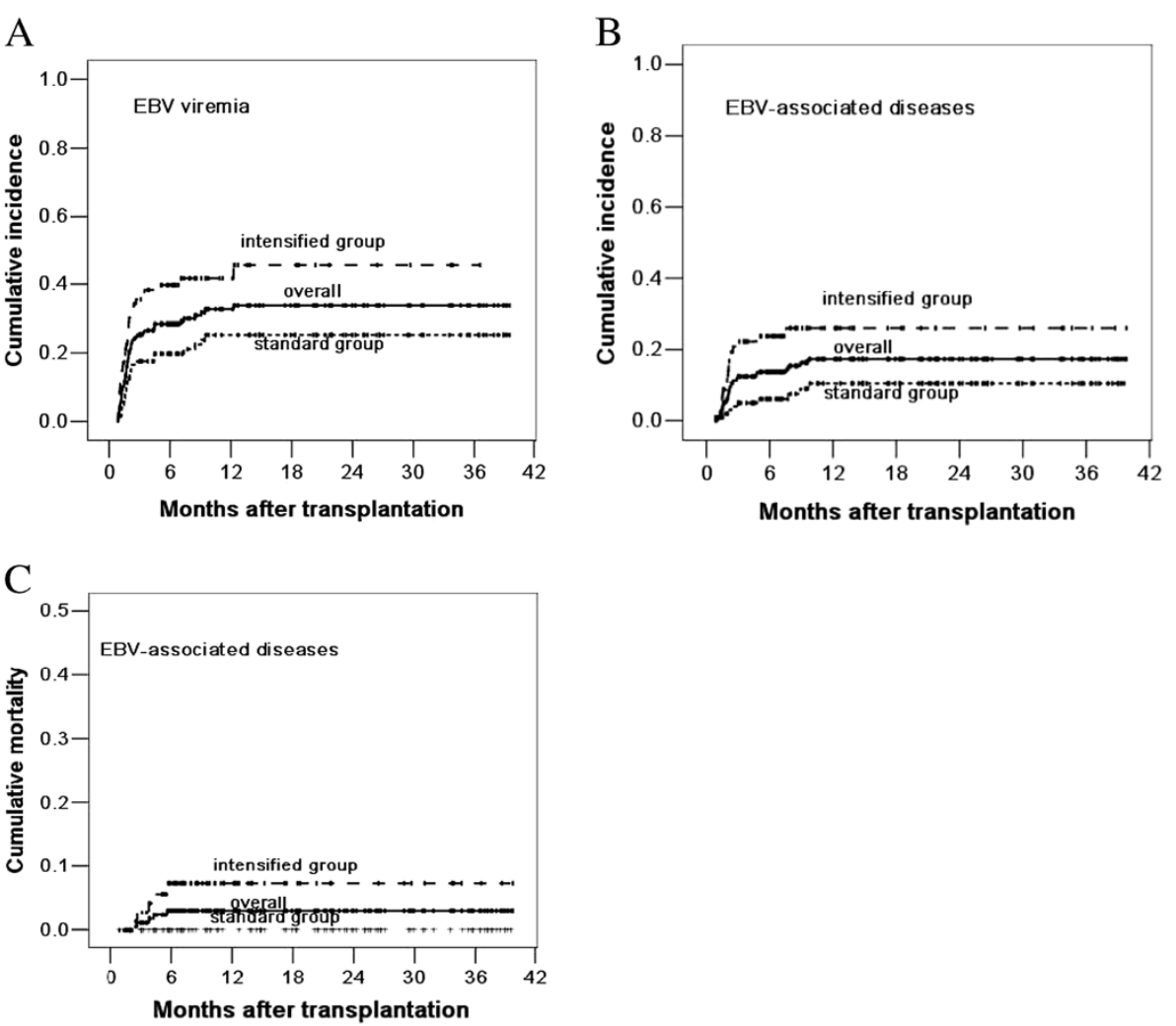

Figure 1 Cumulative incidence of EBV viremia (A), EBV-associated diseases (B) and mortality of EBV-associated diseases (C). The 3-year cumulative incidence of EBV viremia and EBV-associated diseases were $25.3 \% \pm 4.6 \%$ and $10.5 \% \pm 3.4 \%$ in the standard group, compared with $45.6 \% \pm 6.5 \%$ and $26.0 \% \pm 5.3 \%$ in the intensified group $(P=0.002, P=0.002)$. The 3 -year cumulative mortality of EBV-associated diseases was $0.0 \% \pm 0.0 \%$ and $7.3 \% \pm 3.1 \%$ in the standard and intensified group, respectively $(P=0.008)$ 

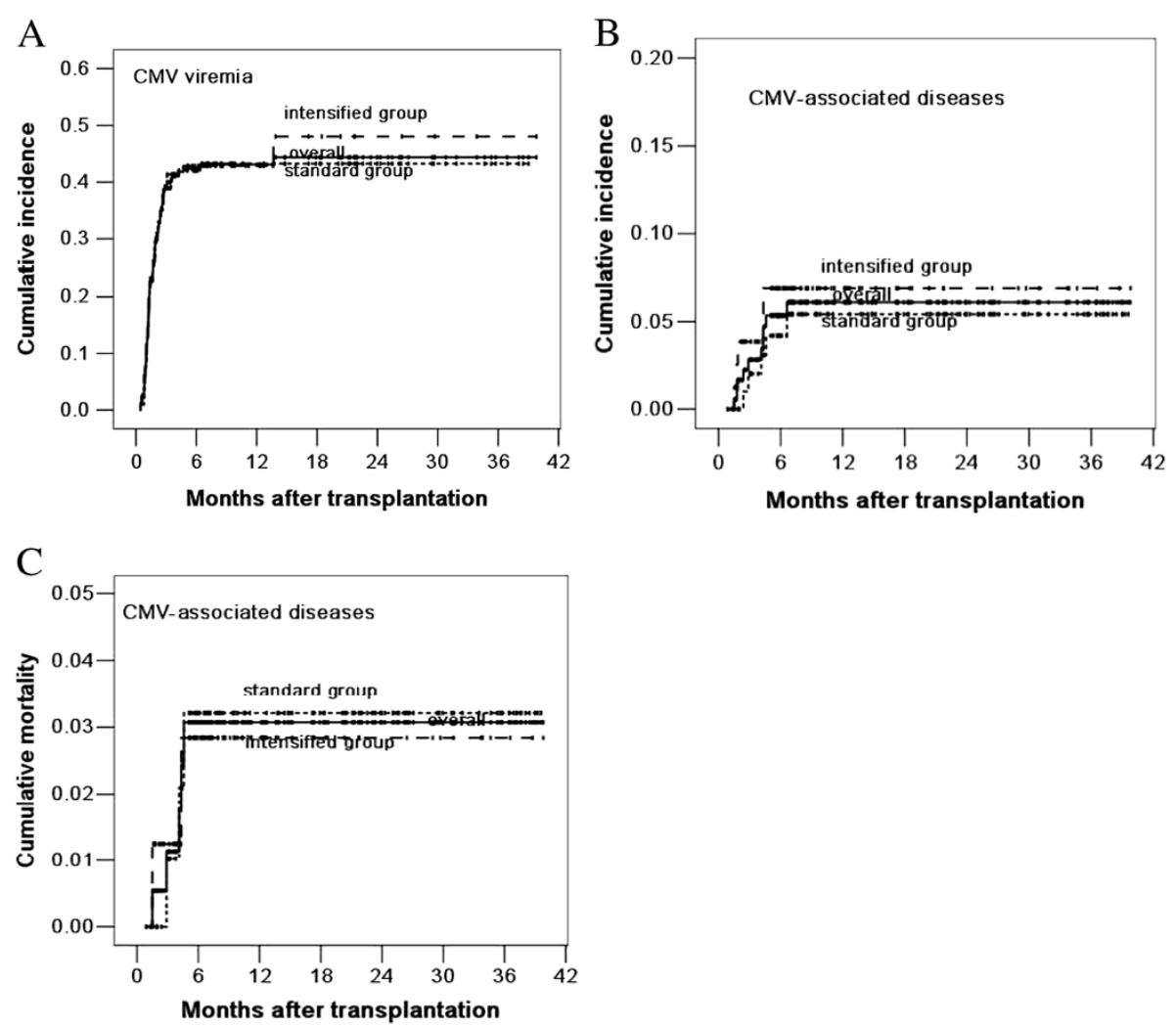

Figure 2 Cumulative incidence of CMV viremia (A), CMV-associated diseases (B) and mortality of CMV-associated diseases (C). The 3-year cumulative incidence of CMV viremia and CMV-associated diseases were $43.3 \% \pm 4.9 \%$ and $5.4 \% \pm 2.4 \%$ in the standard group, compared with $48.1 \% \pm 7.1 \%$ and $6.9 \% \pm 3.0 \%$ in the intensified group $(P=0.855, P=0.581)$. The 3 -year cumulative mortality of CMV-associated diseases was $3.2 \% \pm 1.8 \%$ and $2.9 \% \pm 2.0 \%$ in the standard and intensified group, respectively $(P=0.933)$.

intensified group died of EBV-associated diseases. The 3-year cumulative mortality of EBV-associated diseases was $0.0 \% \pm 0.0 \%$ and $7.3 \% \pm 3.1 \%$ in the standard and intensified group, respectively $(P=0.008)$ (Figure $1 C$ ).

\section{CMV viremia and CMV-associated diseases}

Seventy-seven cases (41.6\%) developed CMV viremia and 10 (4.9\%) developed CMV-associated diseases including $4 \mathrm{CMV}$ pneumonia, $1 \mathrm{CMV}$ encephalitis, 3 CMV enteritis, 1 CMV encephalitis together with enteritis as well as $1 \mathrm{CMV}$ pneumonia together with encephalitis. The median time to onset of CMV viremia and CMV-associated diseases was 41 days (range, 11410 days) and 106 days (range, 45-198 days) post-transplantation, respectively.

CMV viremia occurred in $43(41.3 \%)$ cases in the standard group and $34(42.0 \%)$ cases in the intensified group $(P=0.931)$. CMV-associated diseases occurred in $5(4.8 \%)$ cases in the standard group and $5(6.2 \%)$ cases in the intensified group $(P=0.684)$. The 3 -year cumulative incidence of CMV viremia and CMV-associated diseases were $43.3 \% \pm 4.9 \%$ and $5.4 \% \pm 2.4 \%$ in the standard group, compared with $48.1 \% \pm 7.1 \%$ and $6.9 \% \pm 3.0 \%$ in the intensified group $(P=0.855, P=0.581$, respectively, log-rank test, Figure $2 \mathrm{~A}$ and $2 \mathrm{~B}$ ). Three cases in the standard group and two cases in the intensified group died of CMV-associated diseases. The 3-year cumulative mortality of CMV-associated diseases was $3.2 \% \pm 1.8 \%$ and $2.9 \% \pm 2.0 \%$ in the standard and intensified group, respectively $(P=0.933)$ (Figure $2 \mathrm{C}$ ).

\section{Risk factors for EBV and CMV infections}

Univariate and multivariate analysis about the risk factors for EBV and CMV infections are showed in Table 2. On multivariate analysis, only use of ATG (relative risk $[R R]=15.554,95 \%$ confidence interval $[C I]: 6.598$ 36.664, $P<0.001 ; \quad R R=19.216$, 95\% CI: 4.525-81.598, $P<0.001$, respectively) and intensified conditioning regimens $(R R=1.759,95 \% C I$ : 1.034-2.991, $P=0.037 ; R R$ $=2.290,95 \%$ CI: 1.051-4.994, $P=0.037$, respectively) were the risk factors for EBV viremia and EBV-associated diseases; HLA mismatch $(R R=2.441,95 \% C I$ : $1.551-3.840$, $P<0.001)$ and early CsA withdrawal $(R R=2.112,95 \% C I$ : 1.307-3.412, $P=0.002)$ were the risk factors for $\mathrm{CMV}$ viremia; aGVHDII-IV $(R R=12.554, \quad 95 \% \quad C I$ : 1.570 100.401, $P=0.017$ ) was the only risk factor for CMV- 
Table 2 Univariate and multivariate analyses of risk factors for EBV and CMV infections after allo-HSCT

\begin{tabular}{|c|c|c|c|c|c|c|c|c|}
\hline \multirow[t]{2}{*}{ Risk factors } & \multicolumn{2}{|c|}{ EBV viremia } & \multicolumn{2}{|c|}{ EBV-associated diseases } & \multicolumn{2}{|c|}{ CMV viremia } & \multicolumn{2}{|c|}{ CMV-associated disease } \\
\hline & Univariate & $\begin{array}{l}\text { Multivariate } \\
\text { (RR) }\end{array}$ & Univariate & $\begin{array}{l}\text { Multivariate } \\
\text { (RR) }\end{array}$ & Univariate & $\begin{array}{l}\text { Multivariate } \\
\text { (RR) }\end{array}$ & Univariate & $\begin{array}{l}\text { Multivariate } \\
\text { (RR) }\end{array}$ \\
\hline male vs female & NS & NS & NS & NS & NS & NS & NS & NS \\
\hline $\begin{array}{l}\text { Age, }<20 \text { years vs } \geq 20 \text { to } \leq 40 \text { years } \\
\text { vs }>40 \text { years }\end{array}$ & NS & NS & NS & NS & NS & NS & NS & NS \\
\hline Disease status, CR vs NR & $P=0.029$ & NS & NS & NS & NS & NS & NS & NS \\
\hline Related vs unrelated donor & $P<0.001$ & NS & $P<0.001$ & NS & NS & NS & NS & NS \\
\hline HLA typing, matched vs mismatched & $P<0.001$ & NS & $P<0.001$ & NS & $P<0.001$ & $P<0.001(2.441)$ & NS & NS \\
\hline Standard vs intensified conditioning & $P=0.002$ & $\begin{array}{l}P=0.037 \\
(1.759)\end{array}$ & $P=0.006$ & $\begin{array}{l}P=0.037 \\
(2.290)\end{array}$ & NS & NS & NS & NS \\
\hline EBV serological matches vs mismatches & NS & NS & NS & NS & NS & NS & NS & NS \\
\hline CMV serological matches vs mismatches & NS & NS & NS & NS & NS & NS & NS & NS \\
\hline ATG vs no ATG & $P<0.001$ & $\begin{array}{l}P<0.001 \\
(15.554)\end{array}$ & $P<0.001$ & $\begin{array}{l}P<0.001 \\
(19.216)\end{array}$ & $P<0.001$ & NS & $P=0.006$ & NS \\
\hline Flu vs no Flu & NS & NS & NS & NS & NS & NS & NS & NS \\
\hline Acute GVHD II-IV vs 0-I & NS & NS & $P=0.032$ & NS & $P<0.001$ & NS & $P=0.002$ & $\begin{array}{l}P=0.017 \\
(12.554)\end{array}$ \\
\hline Chronic GVHD vs no cGVHD & NS & NS & NS & NS & NS & NS & NS & NS \\
\hline $\begin{array}{l}\text { Early CSA withdrawal vs no early } \\
\text { withdrawal }\end{array}$ & NS & NS & NS & NS & $P<0.001$ & $\begin{array}{l}P=0.002 \\
(2.112)\end{array}$ & NS & NS \\
\hline DLI vs no DLI & NS & NS & NS & NS & $P=0.010$ & NS & NS & NS \\
\hline
\end{tabular}

$R R=$ relative risk; $v s=$ versus; $C R=$ complete remission; $N R=$ not in $C R ; H L A=$ human leukocyte antigen; $E B V=$ Epstein-Barr virus; $C M V=C y t o m e g a l o v i r u s ; A T G=$ antithymocyte globulin; $F L U=$ fludarabine; $G V H D=$ graft-versus-host disease; $C S A=$ cyclosporine $A ; D L I=$ donor lymphocyte infusion; $N S=$ not significant.

associated diseases. In contrast, age, sex, EBV and CMV serological status, use of Flu and the occurrence of cGVHD did not show any significant influence on the risk of EBV and CMV infections.

\section{Immune reconstitution}

The total lymphocyte counts at 1,3 and 6 months after transplantation were $(0.686 \pm 0.453) \times 10^{9} / \mathrm{L}$, $(1.463 \pm 0.878) \times 10^{9} / \mathrm{L}$ and $(1.512 \pm 0.916) \times 10^{9} / \mathrm{L}$ in the standard group, compared with $(0.709 \pm 0.390) \times 10^{9} / \mathrm{L}$, $(1.237 \pm 0.682) \times 10^{9} / \mathrm{L}$ and $(1.566 \pm 0.763) \times 10^{9} / \mathrm{L}$ in the intensified group $(P=0.510, P=0.082, P=0.354$, respectively). The percentage of $\mathrm{CD} 4^{+} \mathrm{T}$ cells and ratio of $\mathrm{CD}^{+} / \mathrm{CD}^{+} \mathrm{T}$ cells in the standard group at 3 months post-transplantation were significantly higher than that in the intensified group $(P=0.032$, $P=0.022$ ). The percentages of $\mathrm{CD}^{+}{ }^{+} \mathrm{T}$ cells, $\mathrm{CD}^{+} \mathrm{T}$ cells, CD19 ${ }^{+} \mathrm{B}$ cells and $\mathrm{CD} 16^{+} \mathrm{CD}^{-} 6^{+} \mathrm{NK}$ cells at 3 months post-transplantation were similar between standard and intensified group (all $P>0.05$ ). The percentages of all cell subsets at 1 and 6 months posttransplantation did not differ significantly between standard and intensified group (all $P>0.05$ ).

\section{OS and DFS}

With a median follow up of 10.6 months (range, 0.9 to 39.8 months), 117 cases were alive. Thirty-three cases in the standard group and 35 in the intensified group died. Comparing standard versus intensified regimens, the causes of death included leukemia relapse $(n=18$ vs 14$)$, GVHD ( $\mathrm{n}=7$ vs 8 ), infections ( $\mathrm{n}=5$ vs 7 ), RRT ( $\mathrm{n}=2$ vs 0 ), EBV-associated diseases ( $\mathrm{n}=0$ vs 5 ) and pulmonary haemorrhage ( $\mathrm{n}=1$ vs 1 ). The 3 -year OS and DFS in the standard group were $62.2 \% \pm 5.8 \%$ and $60.6 \% \pm 5.6 \%$, compared with $51.6 \% \pm 6.2 \%$ and $51.1 \% \pm 5.9 \%$ in the intensified group, respectively $(P=0.029, P=0.063$, logrank test). The 3-year cumulative incidence of relapse and nonrelapse TRM were $28.1 \% \pm 5.7 \%$ and $18.1 \% \pm 4.8 \%$ in the standard group, compared with $38.2 \% \pm 8.9 \%$ and $27.8 \% \pm 5.2 \%$ in the intensified group, respectively $(P=0.209, P=0.030$, log-rank test).

\section{Discussion}

In allo-HSCT, the relapse of the underlying disease is the main factor that affects survival. The intensity of conditioning regimen has been shown to directly affect the relapse and survival $[30,31]$. Some studies suggested that intensified conditioning could reduce tumor relapse, but it might simutaneously increase TRM including infection-related mortality [10-12]. In addition to the anti-tumor effect of conditioning regimens, the therapeutic efficacy of allo-HSCT also relies on the graftversus-tumor (GVT) effect $[1,32]$. In this study, based on the results of our previous studies [13], we 
introduced the regimen of intensified conditioning, early tapering of prophylactic immunosuppressants followed by DLI for inducing GVT effect for patients with highrisk and refractory hematological malignancies, with 3year OS and DFS of $51.6 \% \pm 6.2 \%$ and $51.1 \% \pm 5.9 \%$. The results once again proven that intensified conditioning followed by inducing GVT effect was effective for patients with high-risk and refractory hematological malignancies.

Infections are another leading cause of death after allo-HSCT. Some studies reported that the incidence of infections and the infection-related mortality might reach up to $77 \%$ and $20 \%$ after allo-HSCT, respectively $[3,33,34]$. Recently, with wide applications of antibacterial and antifungal drugs in the prophylaxis and therapy of infections, the incidence and mortality of bacterial and fungal infections post-transplantation decrease markedly. However, due to the absence of effective preventive and therapeutic drugs for most viruses, the incidence and mortality of viral infections increase relatively, especially in the early period after transplantation. Some studies suggested that intensified conditioning was accompanied by an increasing incidence and mortality of early-stage infections, due to aggravated tissue and organ damage as well as the delay of immune reconstitution after HSCT [10-12]. In this study, we prospectively compared the effects of standard and intensified conditioning on infections, especially EBV and CMV infections. Our data further confirmed our previous results that intensified conditioning did not increase the incidence and mortality of bacterial and fungal infections early post-transplantation [13]. Meanwhile, our data showed that intensified conditioning might increase the incidence of EBV viremia and EBV-associated diseases as well as the mortality of EBV-associated diseases, but it did not affect the incidence of CMV viremia and CMV-associated diseases as well as the mortality of CMV-associated diseases. The differences might be associated with the fact that there was optimal strategy for prevention and treatment of CMV infections, but lack of effective methods to prevent and treat EBV infections.

Although EBV and CMV infections are the most common opportunistic viral infections and closely related to the immune function, the risk factors for both infections are different in recipients of allo-HSCT. Recognized main risk factors for EBV infections include T-cell depletion, use of ATG or anti-CD3 monoclonal antibody, HLA mismatch, unrelated donor and so on [35-38]. Important risk factors for $\mathrm{CMV}$ infections are associated with the serological status of donor and recipient, aGVHD, T-cell depletion and use of ATG $[18,23]$. In this study, we analyzed the risk factors for EBV and CMV infections. Univariate analysis revealed that HLA mismatch, unrelated donor, use of ATG, advanced disease status and aGVHDII-IV were associated with EBV infections; use of ATG, aGVHDII-IV, HLA mismatch, early CsA withdrawal and DLI were associated with CMV infections. Upon multivariate analysis, use of ATG was found to be the risk factor for EBV viremia and EBVassociated diseases; HLA mismatch and early CsA withdrawal were the risk factors for CMV viremia; aGVHDII-IV was the only risk factor for CMVassociated diseases. These results were consistent with current studies $[18,23,36,38]$, except the finding that CMV infections was associated with early CsA withdrawal and DLI. The reasonable explanation for this finding was that early CsA withdrawal or DLI could increase the incidence of GVHD, and GVHD was the risk factor for CMV infections. Interestingly, univariate and multivariate analysis both revealed that intensified conditioning was the risk factor for EBV viremia and EBVassociated diseases. The mechanisms that intensified conditioning increased EBV infections might be associated with the effects of intensified conditioning on early immune reconstitution. Therefore, we analyzed the immune reconstitution of recipients early posttransplantation and found that the percentage of $\mathrm{CD} 4^{+}$ $\mathrm{T}$ cells and ratio of $\mathrm{CD} 4^{+} / \mathrm{CD}^{+} \mathrm{T}$ cells at 3 months post-transplantation were significantly lower in the intensified group.

\section{Conclusions}

Intensified conditioning represents a promising approach for high-risk hematological malignancies, although it affects early immune reconstitution of recipients and increases the incidence and mortality of EBV infections.

\section{Competing interests}

The authors declare that they have no competing interests.

\section{Authors' contributions}

LX performed investigations, analyzed data and wrote the paper; FH, ZPF, HSZ and XZ analyzed data; GPY, YZ, CL and JS performed investigations; QFL designed the study and wrote the paper. All authors read and approved the final manuscript.

\section{Acknowledgements}

This work was supported by the National Natural Science Foundation of China (Grant No.81000231, No.30971300), the Research Fund for the Doctoral Program of Higher Education of China (Grant No. 20104433110003), the Science and Technology Project of Guangdong Province of China (Grant No.2009A030200007) and National Public Health Grand Research Foundation (Grant No. 201202017).

Received: 26 June 2012 Accepted: 25 July 2012

Published: 2 August 2012

\section{References}

1. Schmid C, Schleuning M, Schwerdtfeger R, Hertenstein B, Mischak-Weissinger E, Bunjes D, Harsdorf SV, Scheid C, Holtick U, Greinix H, Keil F, Schneider B, Sandherr M, Bug G, Tischer J, Ledderose G, Hallek M, Hiddemann W, Kolb $\mathrm{HJ}$ : Long-term survival in refractory acute myeloid leukemia after sequential treatment with chemotherapy and reduced-intensity 
conditioning for allogeneic stem cell transplantation. Blood 2006, 108:1092-1099.

2. LV M, Huang $X$ : Allogeneic hematopoietic stem cell transplantation in China: where we are and where to go. J Hematol Oncol 2012, 5:10.

3. Martin-Pena A, Aguilar-Guisado M, Espigado I, Parody R, Miguel Cisneros J: Prospective study of infectious complications in allogeneic hematopoietic stem cell transplant recipients. Clin Transplant 2011, 25:468-474.

4. Mato AR, Morgans A, Luger SM: Novel strategies for relapsed and refractory acute myeloid leukemia. Curr Opin Hematol 2008, 15:108-114.

5. Ringden O, Labopin M, Tura S, Arcese W, Iriondo A, Zittoun R, Sierra J, Gorin $\mathrm{NC}$ : A comparison of busulphan versus total body irradiation combined with cyclophosphamide as conditioning for autograft or allograft bone marrow transplantation in patients with acute leukaemia. Acute Leukaemia Working Party of the European Group for Blood and Marrow Transplantation (EBMT). Br J Haematol 1996, 93:637-645

6. Giralt S, Thall PF, Khouri I, Wang X, Braunschweig I, Ippolitti C, Claxton D, Donato M, Bruton J, Cohen A, Davis M, Andersson BS, Anderlini P, Gajewski J, Kornblau S, Andreeff M, Przepiorka D, Ueno NT, Molldrem J, Champlin R: Melphalan and purine analog-containing preparative regimens: reducedintensity conditioning for patients with hematologic malignancies undergoing allogeneic progenitor cell transplantation. Blood 2001, 97:631-637.

7. McSweeney PA, Niederwieser D, Shizuru JA, Sandmaier BM, Molina AJ, Maloney DG, Chauncey TR, Gooley TA, Hegenbart U, Nash RA, Radich J, Wagner JL, Minor S, Appelbaum FR, Bensinger WI, Bryant E, Flowers ME, Georges GE, Grumet FC, Kiem HP, Torok-Storb B, Yu C, Blume KG, Storb RF: Hematopoietic cell transplantation in older patients with hematologic malignancies: replacing high-dose cytotoxic therapy with graft-versustumor effects. Blood 2001, 97:3390-3400.

8. Gurman G, Arat M, Ilhan O, Konuk N, Beksac M, Celebi H, Ozcan M, Arslan O, Ustun C, Akan H, Uysal A, Koc H: Allogeneic hematopoietic cell transplantation without myeloablative conditioning for patients with advanced hematologic malignancies. Cytotherapy 2001, 3:253-260.

9. Gutierrez-Aguirre $\mathrm{CH}$, Cantu-Rodriguez OG, Gonzalez-Llano O, Salazar-Riojas R, Martinez-Gonzalez O, Jaime-Perez JC, Morales-Toquero A, Tarin-Arzaga LC, Ruiz-Arguelles GJ, Gomez-Almaguer D: Non-myeloablative hematopoietic stem cell transplantation is of limited value in advanced or refractory acute myeloblastic leukemia. The Mexican experience. Hematology 2007, 12:193-197.

10. Aschan J: Risk assessment in haematopoietic stem cell transplantation: conditioning. Best Pract Res Clin Haematol 2007, 20:295-310.

11. Engelhard D, Elishoov H, Or R, Naparstek E, Nagler A, Strauss N, Cividalli G, Aker M, Ramu N, Simhon A, et al: Cytosine arabinoside as a major risk factor for Streptococcus viridans septicemia following bone marrow transplantation: a 5-year prospective study. Bone Marrow Transplant 1995, 16:565-570.

12. Mengarelli A, lori A, Guglielmi C, Romano A, Cerretti R, Torromeo C, Micozzi A, Fenu S, Laurenti L, Donato V, De Felice L, Arcese W: Standard versus alternative myeloablative conditioning regimens in allogeneic hematopoietic stem cell transplantation for high-risk acute leukemia. Haematologica 2002, 87:52-58.

13. Liu QF, Fan ZP, Zhang Y, Jiang ZJ, Wang CY, Xu D, Sun J, Xiao Y, Tan H: Sequential intensified conditioning and tapering of prophylactic immunosuppressants for graft-versus-host disease in allogeneic hematopoietic stem cell transplantation for refractory leukemia. Biol Blood Marrow Transplant 2009, 15:1376-1385.

14. Liu YC, Lu PL, Hsiao HH, Chang CS, Liu TC, Yang WC, Lin SF: Cytomegalovirus infection and disease after allogeneic hematopoietic stem cell transplantation: experience in a center with a high seroprevalence of both CMV and hepatitis B virus. Ann Hematol 2012, 91:587-595.

15. Ljungman P, Griffiths P, Paya C: Definitions of cytomegalovirus infection and disease in transplant recipients. Clin Infect Dis 2002, 34:1094-1097.

16. Meijer $E_{1}$ Cornelissen JJ: Epstein-Barr virus-associated lymphoproliferative disease after allogeneic haematopoietic stem cell transplantation: molecular monitoring and early treatment of high-risk patients. Curr Opin Hematol 2008, 15:576-585.

17. Liu QF, Fan ZP, Luo XD, Sun J, Zhang Y, Ding YQ: Epstein-Barr virusassociated pneumonia in patients with post-transplant lymphoproliferative disease after hematopoietic stem cell transplantation. Transpl Infect Dis 2010, 12:284-291.

18. Jaskula E, Dlubek D, Sedzimirska M, Duda D, Tarnowska A, Lange A: Reactivations of cytomegalovirus, human herpes virus 6, and EpsteinBarr virus differ with respect to risk factors and clinical outcome after hematopoietic stem cell transplantation. Transplant Proc 2010, 42:3273-3276

19. Olkinuora H, von Willebrand E, Kantele JM, Vainio O, Talvensaari K, SaarinenPihkala $U$, Siitonen S, Vettenranta K: The impact of early viral infections and graft-versus-host disease on immune reconstitution following paediatric stem cell transplantation. Scand J Immunol 2011, 73:586-593.

20. Kim SY, Lee DG, Kim MS, Kim HJ, Lee S, Min CK: The influence of infection early after allogeneic stem cell transplantation on the risk of leukemic relapse and graft-versus-host disease. Am J Hematol 2008, 83:784-788.

21. Reddy N, Rezvani K, Barrett AJ, Savani BN: Strategies to prevent EBV reactivation and posttransplant lymphoproliferative disorders (PTLD) after allogeneic stem cell transplantation in high-risk patients. Biol Blood Marrow Transplant 2011, 17:591-597.

22. Jimenez M, Ercilla G, Martinez C: Immune reconstitution after allogeneic stem cell transplantation with reduced-intensity conditioning regimens. Leukemia 2007, 21:1628-1637.

23. Junghanss C, Boeckh M, Carter RA, Sandmaier BM, Maris MB, Maloney DG, Chauncey T, McSweeney PA, Little MT, Corey L, Storb R: Incidence and outcome of cytomegalovirus infections following nonmyeloablative compared with myeloablative allogeneic stem cell transplantation, a matched control study. Blood 2002, 99:1978-1985.

24. Suminoe A, Matsuzaki A, Koga Y, Kusuhara K, Hara T: Human herpesvirus 6 (HHV-6)-associated pleurisy after unrelated cord blood transplantation in children with chemotherapy-resistant malignant Lymphoma. J Pediatr Hematol Oncol 2007, 29:709-712.

25. Peres RM, Costa CR, Andrade PD, Bonon SH, Albuquerque DM, de Oliveira C, Vigorito AC, Aranha FJ, de Souza CA, Costa SC: Surveillance of active human cytomegalovirus infection in hematopoietic stem cell transplantation (HLA sibling identical donor): search for optimal cutoff value by real-time PCR. BMC Infect Dis 2010, 10:147.

26. Swerdlow SH, Webber SA, Chadburn A, Ferry JA: Post-transplant lymphoproliferative disorders. World Health Organization Classification of Tumours of Haematopoietic and Lymphoid Tissues. Lyon: IARC Press; 2008:343-349.

27. Wagner HJ, Rooney CM, Heslop HE: Diagnosis and treatment of posttransplantation lymphoproliferative disease after hematopoietic stem cell transplantation. Biol Blood Marrow Transplant 2002, 8:1-8.

28. Styczynski J, Reusser P, Einsele H, de la Camara R, Cordonnier C, Ward KN, Ljungman P, Engelhard D: Management of HSV, VZV and EBV infections in patients with hematological malignancies and after SCT: guidelines from the Second European Conference on Infections in Leukemia. Bone Marrow Transplant 2009, 43:757-770.

29. Kinch A, Oberg G, Arvidson J, Falk Kl, Linde A, Pauksens K: Post-transplant lymphoproliferative disease and other Epstein-Barr virus diseases in allogeneic haematopoietic stem cell transplantation after introduction of monitoring of viral load by polymerase chain reaction. Scand J Infect Dis 2007, 39:235-244

30. Mineishi S, Longo WL, Atkinson ME, Smith EP, Hamielec M, Wiersma SR, Kinsella TJ, Schuening FG: Addition of high-dose Ara-C to the BMT conditioning regimen reduces leukemia relapse without an increase in toxicity. Bone Marrow Transplant 1999, 23:1217-1222.

31. de Lima M, Anagnostopoulos A, Munsell M, Shahjahan M, Ueno N, Ippoliti C, Andersson BS, Gajewski J, Couriel D, Cortes J, Donato M, Neumann J, Champlin R, Giralt S: Nonablative versus reduced-intensity conditioning regimens in the treatment of acute myeloid leukemia and high-risk myelodysplastic syndrome: dose is relevant for long-term disease control after allogeneic hematopoietic stem cell transplantation. Blood 2004, 104:865-872.

32. Peggs KS, Thomson K, Hart DP, Geary J, Morris EC, Yong K, Goldstone AH, Linch DC, Mackinnon S: Dose-escalated donor lymphocyte infusions following reduced intensity transplantation: toxicity, chimerism, and disease responses. Blood 2004, 103:1548-1556.

33. Frere $P$, Baron $F$, Bonnet $C$, Hafraoui $K$, Pereira M, Willems E, Fillet $G$, Beguin $Y$ : Infections after allogeneic hematopoietic stem cell transplantation with a nonmyeloablative conditioning regimen. Bone Marrow Transplant 2006, 37:411-418. 
34. Gratwohl A, Brand R, Frassoni F, Rocha V, Niederwieser D, Reusser P, Einsele $\mathrm{H}$, Cordonnier $\mathrm{C}$ : Cause of death after allogeneic haematopoietic stem cell transplantation (HSCT) in early leukaemias: an EBMT analysis of lethal infectious complications and changes over calendar time. Bone Marrow Transplant 2005, 36:757-769.

35. Omar H, Hagglund $\mathrm{H}$, Gustafsson-Jernberg A, LeBlanc K, Mattsson J, Remberger M, Ringden O, Sparrelid E, Sundin M, Winiarski J, Yun Z, Ljungman P: Targeted monitoring of patients at high risk of posttransplant lymphoproliferative disease by quantitative Epstein-Barr virus polymerase chain reaction. Transpl Infect Dis 2009, 11:393-399.

36. Landgren O, Gilbert ES, Rizzo JD, Socie G, Banks PM, Sobocinski KA, Horowitz MM, Jaffe ES, Kingma DW, Travis LB, Flowers ME, Martin PJ, Deeg $\mathrm{HJ}$, Curtis RE: Risk factors for lymphoproliferative disorders after allogeneic hematopoietic cell transplantation. Blood 2009, 113:4992-5001.

37. Brunstein CG, Weisdorf DJ, DeFor T, Barker JN, Tolar J, van Burik JA, Wagner JE: Marked increased risk of Epstein-Barr virus-related complications with the addition of antithymocyte globulin to a nonmyeloablative conditioning prior to unrelated umbilical cord blood transplantation. Blood 2006, 108:2874-2880

38. Wu XL, Liu QF: Epstein - Barr virus - associated Diseases in Allogeneic Hematopoietic Stem Cell Transplantation. J Hematol Oncol 2012, 5(Suppl 1):A8

doi:10.1186/1756-8722-5-46

Cite this article as: Xuan et al:: Effects of intensified conditioning on Epstein-Barr virus and cytomegalovirus infections in allogeneic hematopoietic stem cell transplantation for hematological malignancies. Journal of Hematology \& Oncology 2012 5:46.

\section{Submit your next manuscript to BioMed Central and take full advantage of:}

- Convenient online submission

- Thorough peer review

- No space constraints or color figure charges

- Immediate publication on acceptance

- Inclusion in PubMed, CAS, Scopus and Google Scholar

- Research which is freely available for redistribution 